\title{
Поповський А.
}

\section{ДЕЩИЦЯ ПРО УКРАЇНСЬКІ ПРІЗВИЩА}

\author{
Дніпро : Лipa, 2020. 300 c.
}

Визначальною частиною власної назви кожної особи поряд 3 ім'ям є також їі прізвище. У слов'янських народів воно ідентифікує їі родову належність, що передається від покоління до покоління протягом тривалого часу і вказує на спорідненість певної групи людей. Ім’я і прізвище особи може бути одним із засобів їі етнічної ідентифікації.

Українські прізвища мають дуже розгалужену систему формування. За прізвищем досить часто можна визначити ймовірний регіон і навіть місцевість України, 3 якої походив предок-засновник роду, припустити його професію чи рід занять, звання, чин, суспільне становище, а також особливі прикмети зовнішності, одягу, поведінки, уподобань, фізичні вади і т. ін. Прізвища можуть мати різні фонетико-морфологічні варіанти і трансформуватися. На їх основі могли створюватися інші прізвища.

Українські прізвища вже досліджували Ю. К. Редько, В. О. Горпинич, А. М. Поповський, І. Д. Фаріон, Л. О. Кравченко, Н. Ю. Булава, П. П. Чучка, В. П. Буркат, Ю. М. Новикова, Є. О. Бадін, Р. М. Падалка, К. Д. Глуховцева, І. А. Корнієнко, В. М. Демченко, І. П. Лопушанський, О. В. Хвіщук та ін. Нова праця доктора філологічних наук, професора А. М. Поповського про українські прізвища стане істотним поповненням української ономатології.

Актуальність і навіть необхідність своєї монографії визначив сам автор: «До цієї праці спонукала мене дрімуча байдужість значного українського загалу до пізнання походження свого імені, прізвища, прізвиська, таємничої крони історичного древа свого ж таки родоводу <...>. Унаслідок цього маємо наплив таких імен, як $A л i-$ ка, Альона, Анжеліка, Віолетта, Віола, Дар'я, Дана, Каміла, Карина, Ліана, Даниїл, Кіріл, Артур, Макс і тому подібні. Ще більше спостерігаємо свідомих спотворень українських прізвищ як їх носіями, так і чиновниками різних адміністративних інстанцій» (с. 5). «По суті, — продовжує автор, — це питання має бути опрацьоване науковцями й висвітлене у дисертаційних дослідженнях, засобах масової інформації для широкого українського загалу, а також у різножанрових публікаціях $<\ldots .>$. То ж коли питання історії родоводу і його змісту, закарбованого в прізвищі, стане такою життєвою необхідністю, як повітря для всього сущого, лише тоді проснеться душа українська від вікових колоніальних стереотипів рабоприслужницького “лукавого слов'янського братства” й потужно запрацює свободолюбивий дух козацької вольності й генетичний код національної свідомості, який так потрібний у вихованні сучасного юнацтва суверенної України» (с. 7, 8).

Рецензована монографія А. М. Поповського - це результат тридцятирічної роботи автора зі збирання, систематизації та наукової інтерпретації величезного обсягу фактичного матеріалу з найрізноманітніших джерел: словників, довідників, енциклопедій, наукових праць, навчальних посібників, художньої, публіцистичної та епістолярної літератури, часописів, альманахів, центральних та регіональних газет, радіо- і телепередач, інтернету, українського фольклору, адресно-телефонних довідників, збірників, вісників, каталогів, бюлетенів, студій, хронік, реєстрів, нарисів, мемуарів, програм наукових конференцій, авторефератів дисертацій i, нарешті, досить багатого авторського архіву1970-2019 рр. і т. ін. При цьому слід зазначити, що всі наведені в монографії прізвища (а їх десятки й сотні) ретельно паспортизовані. Це убезпечило автора від можливих підозр у довільному їх творенні, тобто у фальсифікаціях.

Відомості про українські прізвища автор виклав у 10-ти статтях-нарисах: прізвища із спонукальним компонентом, односкладові прізвища, пов’язані з бджільництвом, з числівниковою основою, із займенниковою основою $c$ as-/caмо-; пов’яза- 
ні $з$ юриспруденцією, з компонентом крив-, 3 компонентом -їд- (-їж-), з компонентом біл- та 3 компонентом лих-. Кожна стаття оформлена як окреме дослідження зі своїми «Бібліографічними посиланнями» та «Умовними скороченнями» джерел, бо автор спочатку публікував їх у мовознавчій періодиці.

Увагу читача привертають насамперед найпоширеніші і, мабуть, одні з найдавніших прізвища зі спонукальними та (рідше) із заборонними компонентами. Вони досить широко засвідчені в українському фольклорі (казкові персонажі Вернигора, Вернидуб, Котигорошко, Крутивус та ін.). Проте, як зазначають історики, активне творення прізвищ такого типу було пов'язане з масовими втечами кріпаків на Запорозьку Січ. Змінені прізвища унеможливлювали поміщицьким посланцям виявляти втікачів за реєстровими списками Війська Запорозького. Відтак серед запорозьких козаків з'являлися Лупиніс, Болиголова, Вирвизуб, Валяйнога, Варивода, Вернишапка, Давиборш, Дерипаска Загубинога, Загубиколесо, Загнибіда, Задериголова, Півторакожуха, Незовибатько і т. ін. Згодом цей тип прізвищ поширився в діловому письмі, в українській демонології, у фольклорі, художній літературі та в пресі, використовувався як псевдоніми тощо.

А. М. Поповський досить детально розглядає моделі лексико-семантичного способу творення таких прізвищ (с. 10-38) і численні приклади подає переважно за абеткою. Вражає зафіксоване автором дієслівне розмаїття перших компонентів зі спонукальним значенням: боли-, валяй-, вари-, вери-, верни-, верти-, вирви-, голи-, гори-, гуляй-, дави-, держи-, дери-, загуби-, задери-, замети-, затули-, звени-, коти-, крути-, куй-, міси-, мори-, обійди-, пали-, перейми-, печи-, поверни-, покинь-, порви-, пройди-, суши-, терпи-, товчи-, тягни-, убий-, иуми- та багато ін., де спонукальна форма дієслова поєднана з іменником або зрідка 3 прикметником: Болибік, Вертиполос, Голиборода, Гориивіт, Гуляйнога, Давимука, Дериведмідь, Задерихвіст, Заметихата, Звенигора, Затуливітер, Куйбіда, Моримуха, Обійдихата, Паливода, Печихліб, Переймивовк, Поверниключ, Порвиштани, Пройдисвіт, Роззяврот, Сушириба, Терпилихо, Товчигречка, Тягнирядно, Тягнибок, Убийвовк, Хвалибога, Шумивода; Бориславський, Вернигородський, Держипільський і т. ін. Такі самі прізвища 3 часткою не мають заперечне або заборонне значення: Небийголова, Небиймуха, Неварикама, Недайборш, Недайборщенко, Недайвода, Недержиторба, Нездіймишапка, Непийвода, Некормигостенко, Несвятипаска і т. ін.

Менш продуктивним виявився зворотний спосіб творення спонукальних прізвищ, при якому дієслово міститься після іменника або займенника: Буревій, Горицвіт, Гречкосій, Добродій, Жорнокуй, Козодій, Лисобий, Лиходій, Маковій, Свинобій, Чародій, Чорторий, Чубобрий, Самограй, Самодій, Самосій і т. ін.

Крім лексико-семантичного способу, автор монографії розглядає й морфологічний спосіб творення спонукальних прізвищ за допомогою префіксів до-, за-, пере-, по-, про-, роз- + спонукальна форма дієслова або іменник: Доскоч, Затуливітер, Пробийголова, Перебийніс, Передерихвіст, Переймивовк, Пройдисвіт, Переплигнирів, Погукай, Пожуй, Покусай, Постривай, Роздай, Роздириоко, Розкладай та ін. (c. 27). Сюди можна додати також реальні, але чомусь не зафіксовані автором прізвища, утворені за допомогою префікса без- + іменник, що означають відсутність якогось предмета або певної ознаки у першоносія прізвища: Бездітний, Беззубченко, Безкишкін, Безкоровайний, Безпалько, Безпояско, Безсмертний тощо. Нам відомі також відсутні в монографії прізвища з префіксом при-: Придибенко, Приймак, Прикордонний, Прилипко, Прилуцький, Пристайко, Приступа, Присяжнюк, Притика, Притула, Приходько, Пришва тощо.

Крім не надто поширеного префіксального способу творення прізвищ, за висновком дослідника, найпродуктивніша афіксація - суфікси -ай (-яй), -ий (-ій), -уй (-юй), -оч: Бажай, Величай, Жбурляй, Гуляй, Пиляй, Змий, Володій, Жирій, Голосуй, Пожуй, Клюй, Плюй, Доскоч, а також дієслова із заперечною часткою не: Недай, Недобий, Незнай, Нестріляй, Нечитай, Нечіпай і т. ін. (с. 27).

Дуже давні в українському антропоніміконі односкладові прізвища. Ще в писемних пам'ятках Київської Русі засвідчені іменні назви Дір, Мал, Тур, Кий, Щек та ін. Подібні прізвища збереглися аж до нашого часу: Гай, Мал, Крив, Вук, Гал, Дир, Драч, Куи, Піп, Строй, Сан, Сим, Чир та ін. (с. 158).

За способом творення відіменних односкладових прізвищ автор монографії виділяє три групи: а) колишні імена, які успадкувалися як прізвища внаслідок переосмислення, тобто ім'я предка без змін стало назвою нащадків (Ждан, Кость, Сай, 
Сак); б) номінації, утворені способом скорочення імені або прізвища (Бар $<$ Бартоломій, Бен < Бендюженко, Паш < Пашко, Павло, Филь < Филимон, Хар < Харитон, Пал < Павло, Рад < Радимир, Сан < Олександр та ін.); в) односкладові прізвища 3 пестливими або згрубілими формами, що виникли внаслідок скорочення основи (Гринь, Зінь, Даць, Луц̧ь, Ксень, Мись, Сень, Стецьь і т. ін.) (с. 158-159).

Важливим джерелом у формуванні односкладових родових прізвищ, за спостереженнями автора, були також етноніми, що відрізняли пришельців від аборигенів (Влох, Грек, Шваб, Швед, Чех, Серб, Прус, Лях), відтопонімічні односкладові антропоніми (Бар, Дон, Керч, Крим), назви комах (Гедзь, Дрік, Жук, Кліш, Трут, Хрущ та ін.), назви рослин та їхніх частин і квітів (Біб, Гриб, Хмель, Хміль, Хрін, Струк, Сук, Мак, Квіт, Цвіт, Куш), назви харчових продуктів і страв (Борщ, Здір, Квас, Книш, Корж та ін.), назви одягу, тканини (Бриль, Лах, Шаль, Шовк), назви акустичних проявів (Гук, Гам, Крик), назви абстрактних понять (Біль, Блуд, Чад, Блат і т. ін.) Незважаючи на те, що односкладові прізвища посідають в українському антропоніміконі стале й вагоме місце, «в їх організації до цих пір лишаються не з'ясованими деякі питання етимології, семантики, дериватології, загальної кількості як власне українських, так і запозичень іншомовних» (с. 162).

У живій народній мові та в діловодстві здавна усталилися прізвища, пов'язані 3 найдавнішим промислом наших предків - бджолярством. «Бджолярі, - констатує А. М. Поповський, - як і лісники, мельники, ковалі пивовари, сприймалися як особистості, що наділені „природними силами” - „професійним чарівництвом”» (c. 164). Найдавнішим було бортницьке (лісове) бджолярство, тобто розведення бджіл у бортях-дуплах дерев або у видовбаних колодах, навішених на дерева, де гніздилися бджоли. Очевидно, від давньоруського бърть «вулик на дереві» за допомогою суфіксів -н-, -ак-, -енк-, -ик-, -ич-, -ськ-, -ук-, -юк-, -як-, -ян- та ін. утворено сучасні українські прізвища Бортей, Бортейчук, Бортенко, Бортненко, Борткевич, Бортко, Бортник, Бортновський, Бортковський, Бортницький, Бортовець, Бортняк, Бортнянський, Бортяк, Бортянко, Бортниченко, Бортюк, Бортнюк, Бортненко, Бортнич, Бортників і т. ін.

Коли бортництво замінилося досконалішим пасічництвом, від слова пасіка виникли нові можливості творення прізвищ на цій основі 3 певними фонетичними варіантами: Пасіка, Пасічний, Пасічник, Пасічниченко, Пасічинський, Пасічнюк, Пасішник, Пасічняк, Пасішняк, Пасічанка, Пасічук, Підпасічний і т. ін. (с. 165-166). А. М. Поповський наводить також багату палітру антропонімів, пов'язаних з видобуванням, збереженням, якістю та використанням меду в побуті, харчовій промисловості, фармакотерапії тощо: Збираймед, Випиймед, Медак, Медаченко, Медаківський, Медвинський, Медениій, Медулич, Медеиький, Медин, Медко, Медина, Мединський, Медииький, Медник, Медовий, Медовик, Медолиз, Медуниия, Медулич, Медун, Медчук, Медушевський, Медушко, Медущак, Медущенко, Медюк, Медуха, Медух, Медюк, Медяний, Медянко, Медченко, Нектарний, Нектаренко, Нектарчук, Перга, Твердомед і т. ін. (с. 167-168).

У бджільництві, крім видобування меду, такою самою найдавнішою й найважливішою справою було переробляння вощини на віск. Мед і віск займали важливе місце в торгівлі Київської Русі з Візантією та країнами Західної Європи. Українські прізвища, пов'язані з восковим промислом, становлять окрему й досить численну групу. Автор монографії назвав майже 70 таких прізвищ, серед яких Віск, Воскань, Воскар, Воскаренко, Воскач, Восківник, Восковиченко, Восковнюк, Восковченко, Воскобой, Воскобойник, Воскобійник, Воскобойниченко, Воскобринник, Восковеиь, Восковський, Воскогон, Воскодав, Воскодавенко, Восколупенко, Восколюб, Восковнюк, Вощак, Вощаний, Вощанка, Вощан, Вощатинський, Вощенко, Вощенихін, Вощилка, Вощило, Вощинар, Вощинін, Вощинчук, Вощинський, Вощенко, Вощевський, Вощинник, Вощинкін, Вощіюк, Вощук і т. ін. (с. 169-170).

На основі зібраного фактичного матеріалу А. М. Поповський дійшов висновку, що «функціональна семантика антропонімів бджільницького походження не є сталою. Вона була тотожною першоносіям та спадкоємцям родинної професії, а потім, утративши реальний зміст, усталилася як офіційна номінативна одиниця роду» (с. 170).

Вельми цікавий у монографії нарис про українські прізвища з числівниковою основою. Він займає лише неповних 8 сторінок, але науковою базою для нього стали аж 110 різних джерел. Прізвища 3 числовим значенням у сучасній мові нейтральні, проте поява їх серед першоносіїв мотивувалася різними причинами. У багатодітних родинах вони могли означати порядок народження дітей (Первак, Первиш, 
Вторак, Третяк, Четвертак, Четверик, П’ятак, П'ятунко, Шостак, Семерак, Восьмак, Дев'ятко), а також національність і соціальний стан (Полулях, Полуииган, Семитурчин, Полукозак, Полупан, Полубоярин, Полубоярський та ін.), адміністративну посаду (Десятник, Десятниченко, Сотник, Сотниченко, Соиький, Тисяиький та ін.), приватну власність (Одноземещь, Однодвореиь, Двокіз, Дворядно, Триліс, Триполенко, П'ятикоп, Семихат, Стокоз, Стокозенко), фізичні особливості та вади людини (Двожильний, Дев 'ятисильний, Одновушко, Одноноздря, Тригуб, Трипалько, Трипуст, Семиборода, Семиволос, Стобреха, Столобенко та ін.), місцевість походження (Дворічанський, П'тигореиь, П'ятихатський, Триліський, Трипільський, Семидолина, Семилуцький) і т. ін. (с. 197).

Дослідження А. М. Поповського засвідчило, що українські прізвища 3 основою кількісних і порядкових числівників творяться від першого десятка, а також від слів сорок, сто і тисяча. Деякі приклади: Одинак, Одинець, Однолько, Одинокий, Одинчак, Одинеиь, Первашка, Перший; Двоєнко, Двояк, Двояківський, Двоян; Трикоша, Тритенко, Тризуб, Трипільський, Третинник, Третеиький, Третяк, Третяченко; Чотирко, Четвертак, Четвертинський; П'ятак, П'ятаченко, П'ятницький; Шістюк, Шістя, Шостак, Шестерик, Шестопал, Шестаківський, Шостакович; Сімко, Сiмович, Сімак, Сімочко, Семирак, Семеренко, Семченко; Восьмак, Осьмака, Осьмачка, Осьмуха; Дев'ятко, Дев'ятин, Дев'яткін; Десятерик, Десятник, Десятниченко; Сорокевич, Сороковик, Сороковський, Сорокун; Стоцький, Сотник, Сотниченко; Тисячник, Тисячний, Тисячнюк і т. ін. (с. 190-196).

Лаконічне твердження автора про те, що «особливою активністю у творенні українських антропонімів відзначається числівник сім, за яким із глибини віків успадкувалися певні народні вірування» (с. 197), можна доповнити додатковою інформацією.

Число сім 3 давніх-давен вважалося особливим і навіть магічним у багатьох народів. 3 історичної та етнографічної літератури відомо, що стародавні тюрки й ацтеки поклонялися одному й тому самому семиголовому божеству. В індуїзмі богиню родючості Манасу зображають у вигляді жінки, голову якої оточують сім змій. На території Євразії семиголовому божеству поклонялися також арійці та шумери. У міфах багатьох народів світу про будову Всесвіту відображено уявлення про сім нерухомих кришталевих сфер, до яких прикріплені зірки та планети. Найголовніша і найвища сфера була вершиною блаженства - «сьомим небом». Цю версію підтримав і давньогрецький філософ Арістотель (384-322 рр. до н. е.) у трактаті «Будова неба». Згодом вислів сьоме небо набув іншого значення і став уживатися для ознаки найвищої міри радості, блаженства, безмежного щастя.

3 давніх часів людям відоме сузір'я «Гідра». У ньому верхівка складається з семи яскравих зірок. У стародавньому Сгипті число сім вважалося символом вічного життя. Мусульмани вірять у те, що Коран начебто був принесений ангелом із сьомого неба, яке згадується в різних місцях цієї пам'ятки. У духовних практиках індуїзму та в багатьох сучасних окультних системах вважається, що енергетична структура людини складається із семи чакр - центрів концентрації космічної енергії.

В юдаїзмі один з найдавніших єврейських релігійних атрибутів - семисвічник Менора разом із Зіркою Давида $є$ найпоширенішими національними і релігійними єврейськими емблемами. Менора зображена на гербі сучасної держави Ізраїль. Семисвічник із сімома лампадами, подібний до Менори, - традиційний запрестольний атрибут православних та греко-католицьких храмів.

Загадкове й магічне число сім засвідчене також в українському фольклорі. Загальновідомі казки «Про мертву царівну і сім богатирів», «Білосніжка і сім гномів», «Вовк і семеро козенят», фігурують «семимильні чоботи», сентенції «сім разів відміряй і один раз відріж», «семеро одного не ждуть». Щось цінне в казках зберігається неодмінно «за сімома замками». Фізична праця вважається ретельною, якщо вона «до сьомого поту». Швидка хода тоді, коли вона «семимильними кроками». Якщо хтось не вміє дотримувати свого слова, часто змінює погляди і рішення, не виконує обіцянок, то в нього «сім п’ятниць на тиждень».

Росіяни кажуть про мудру, кмітливу людину, що вона «семи пядей во лбу» або що вона «семи пядей», припускаючи, що висота чола пропорційна розуму [нагадаємо, що пядь, або чверть, - це давньоруська міра довжини приблизно 17,8 см, що дорівнює відстані між кінцями розтягнутих великого і вказівного пальців (мала п’ядь) або великого пальця і мізинця (велика п’ядь)]. У російській мові також поши- 
рені фразеологізми семеро по лавкам, за семерых, на семи ветрах, семь смертных грехов, ругаться в семь этажей, седьмая вода на киселе, за семь верст киселя хлебать, семь верст до небес тощо.

Популярності числа сім сприяють також предмети і явища реального життя: наша Сонячна система має сім основних планет, є сім чудес світу, сім днів має тиждень. У середньовічних вищих школах слов'яно-греко-латинського типу викладали «сім вільних наук (мистецтв)». У музиці — сім нот гами. Дощова веселка має сім кольорів. У спорті (легкій атлетиці) є семиборство — комбіноване змагання, яке складається з семи вправ.

За народними повір'ями і прикметами, люди, в яких дата народження містить число сім (або воно фігурує у прізвищі), дуже талановиті, винахідливі, успішні, щасливі, яскраві особистості, здатні долати будь-які труднощі. Усі їхні досягнення пов'язані з внутрішньою силою, керованою космічними законами. Тож не дивно, що в українському антропоніміконі автор монографії засвідчив і задокументував прізвища Сімович, Сімочко, Сімперович, Семирак, Семеренко, Семерний, Семиряк, Симирот, Семибаламут, Семибатько, Семиброд, Семивіл, Семивесло, Семиволос, Семибок, Семибрат, Семигал, Семиголовецьь, Семидідько, Семидітко, Семидоиька, Семидочний, Семикінь, Семикобила, Семикобиленко, Семикоз, Семикопенко, Семикопна, Семикос, Семиліт, Семиліто, Семиног, Семинога, Семиноженко, Семиляк, Семинський, Семчинський, Семипол, Семип'ядний, Семисол, Семисал, Семитурчин, Семидух, Семирод, Семироз, Семирозум, Семирозумний, Семирот, Семиряд, Семислав, Семитяга, Семисюк, Семихат, Семиходський, Семиикура, Сімодейко, С $i$ мороз та їх численні фонетичні варіанти (с. 191, 195).

Розглядаючи українські прізвища із займенниковою основою caм/caмo, автор констатує потужну словотвірну й лексичну організацію антропонімічного поля 3 цією основою, що «дає підстави говорити про цілком розгалужену систему творення власних назв (прізвиська та прізвища) в українській мовній картині світу. Дослідження цих процесів являє собою цікаву царину лінгвістики 3 огляду на діалектичний зв'язок власне мовного явища 3 його концептуальним (світоглядним, культурним, духовним) корелятом, що має подальші наукові перспективи їі аналітики» (с. 204).

Словотвірна модель прізвищ з першим компонентом сам/само в українській антропоніміці використовується «для характеристики тієї чи іншої людини, яка діє, виконує щось особисто чи здійснює без стороннього впливу, без будь-якої допомоги тощо» (с. 203). Автор досить докладно розглядає займенникові форми прізвищ, утворені за допомогою афіксів та іменників, прикметників, спонукальних та усічених форм дієслова, деяких вигуків тощо: Самай, Самайда, Самайчук, Саманець, Самарчук, Самарець, Самачко, Самбур, Самжаренко, Самичко, Самійленко, Самбрат, Самовик, Самовол, Самовтіха, Самодід, Самодум, Самойлович, Самоїд, Самопал, Самосват, Самосійко, Самохатній, Самсон, Самусь, Самчук; Самогайський, Самозірський, Самоплавський, Самородний; Самограй, Самогрій, Самодай, Самосій, Самодрагай; Самоброд, Самодум, Самокат, Самолаз, Самопал, Самостріл, Самосуд, Самофал; Самокам, Самогей і т. ін. (с. 191, 195).

У статті про українські прізвища, пов'язані з юриспруденцією, привертає увагу важлива інформація автора 3 історії української юридичної термінології, яка «має глибокі корені» й «бере свій початок від часів Княжої доби ХІ ст.». Проте українські прізвища, пов’язані з цією сферою, виникли значно пізніше: «Літописи та пам'ятки Київської Русі фіксують здебільшого імена Олег, Святослав Ігор, Добриня тощо. Лише з XIII ст. у писемних джерелах зустрічаються додані до імені назви, які можна розглядати як прізвиська чи прізвища. Уперше фіксуються українські антропоніми тодішньої суспільної верхівки в грамотах XIV-XV ст.: князь Іван Васильович Чорторийський, пан Волчко Рогатинський» (с. 218). Основна ж частина населення - селяни мала лише імена та вуличні клички. Постійні родові назви на основі імен (Іванів, Іваненко, Іванченко), назви місця проживання чи походження (Волинюк, Подоляк, Німчук, Швед), назви професії або постійного заняття (Ботник, Маляр, Коваль, Козак), індивідуальних ознак (Головатий, Заїка, Кривий, Рудий) тощо закріпилися за ними аж наприкінці XVIII - початку XIX ст. в умовах Російської та Австро-Угорської імперій (с. 218-219).

Прізвища, пов'язані з юриспруденцією, утворювалися в процесі становлення органів правопорядку та судочинства (Комісаренко, Правник, Правдюк, Свобода, 
Суддя, Присяжний, Судейченко, Суденко, Судиловський, Судник, Судовенко, Судомора, Кривосуд, Правосуд, Самосуд, Судислав і т. ін.). Інша група таких прізвищ виникла в процесі здійснення в українському суспільстві охоронних та громадсько-організаційних функцій, виконавці яких діставали відповідні найменування (Бурмістр, Війт, Війтишин, Війтенко, Війтович, Війтовський, Лановий, Ратушний, Побережний, Осауленко, Жовніренко, Пристав, Соцький, Становий, Тивун і т. ін.). Основою прізвищ, причетних до юриспруденції, ставали також назви установ, де тримали порушників суспільного спокою і злочинців, арештантське приладдя тощо (В 'язень, Тюрменко, Темниченко, Острозький, Кайдан, Кайданович, Диба, Дибенко, Дибииький, Колодієнко, Колодченко і т. ін.) (с. 220-228).

Детально й на належному науковому ріні А. М. Поповський розглянув українські прізвища з основою крив- в аспекті їх семантичної організації, етимології, класифікації та активності функціонування (с. 232-256). «Такі прізвища успадкувалися від прізвиськ, що побутували в живому народному мовленні, характеризуючи вади людського тіла чи особливості одягу тощо» (с. 232).

Серед антропонімів 3 основою крив-, створених на основі індивідуальних ознак людей, найпоширенішими виявилися ті, що стосуються особливостей органів тіла — носа, рота, шиї, рук, ніг, губ, зубів, очей, бороди (кривобород), відображають фізичні вади людини з нейтральним чи співчутливим ставленням до каліцтва (Kpuвий, Кривенький, Кривень, Кривешко, Кривко, Кривуля, Кривулько, Криванчик, Кривиун, Кривущенко і багато ін.), відзначають особливості чоловічого одягу (Кривошапка, Кривошлик, Кривопоясенко), вказують на походження першого носія прізвища 3 конкретного населеного пункту (Крив'яниия, Крив'яничич, Кривляник, Кривляк, Кривський (від сіл Крива та Криве), Кривобильський (село Кривобиль) тощо.

Антропоніми $з$ основою крив- могли творитися також на основі назв хатніх $\mathrm{i}$ придворних споруд (Кривохата, Кривохат, Кривохатько, Кривохиж, Кривохижа, Кривохиженко, Кривосінний (криві сіни), Криворотенко), негативних рис характеру або поведінки (Кривда, Кривдик, Кривдун, Криворутченко і Кривохаб «злодій», Кривоплакса), зовнішніх ознак тварин, яких мав господар (Кривокляча, Кривокобильський, Кривохвіст, Криворіг, Кривороженко, Криволап).

Цілком логічно, що прізвища 3 основою крив-, як і інші оказіоналізми, були найбільше поширені серед винахідливих і дотепних козаків, серед яких найвідоміший - Максим Кривоніс. Автор монографії віднайшов у Реєстрі Війська Запорозького (Чигиринський, Черкаський, Канівський, Корсунський, Білоцерківський, Уманський, Брацлавський і Кальницький полки) понад 80 прізвищ з цією основою.

Даючи загальну характеристику антропонімам з основою крив(о)-, автор наголошує на тому, що всі ознаки якоїсь кривизни (як нейтральні, так і негативні) характеризували лише першого носія прізвища - засновника роду, а його нащадки переважно їх не мали. Більше того, серед носіїв таких прізвищ були і $є$ нині багато відомих громадсько-політичних діячів, славетних постатей України з різних галузей науки, культури, мистецтва і т. ін. (с. 239).

А. М. Поповський подає 20 коротких статей енциклопедичного типу про найвідоміших українців з прізвищами на криво-, серед яких живописці, співак, актриса, хореограф, мистецтвознавець, архітектор, журналісти, поети, прозаїк, учені, громадські діячі (с. 240-244). Завершується цей розділ пронумерованим і паспортизованим повним списком прізвищ досліджуваного типу від Реєстру Війська Запорозького 1649 р. до сучасних лексикографічних записів (208 позицій), який має самостійне наукове значення (с. 248-255).

Українські прізвища з компонентом -їд- (-їж-), пов’язані з уподобанням та споживанням їжі, також закріплювалися за носіями спочатку як прізвиська, а потім успадковувалися за родинами як прізвища. Автор має цілковиту рацію в тому, що «прізвиськові назви виникли в середовищі живого народного мовлення на основі загальновживаних слів типу борщоїд, дармоїд, жабоїд, камоїд, молокоїд, м'ясоїд, куроїд, ракоїд, рибоїд, салоїд, сироїд, юшкоїд та похідних від них» (с. 258). Проте цей компонент уживається і в словах з переносним значенням: буквоїд, мироїд, людоїд, шкапоїд, україноїдство і т. ін.

Автор наводить низку прикладів із сучасної наукової та публіцистичної літератури і з періодичних видань: Качкоїд, Короїд, Куроїд, Куроїденко, Кашеїда, Кашуїиха, Квашоїд, Мухоїд, Сероїжко, Сироїжко, Довгоїда, Малоїд, Скороїд, Неїжхлібенко, Ненаїденко, Ненаїдовський, Переїденко і т. ін., пише про «різноманітні 
фіксації» прізвищ такого типу в українських пам'ятках XV-XXI ст. (с. 265), проте прикладів са́ме $з$ українських пам“яток у монографії немає. Чи зафіксовані вони, наприклад, у детально опрацьованому автором «Реєстрі Війська Запорозького»? Чи 3 цих «різноманітних фіксацій українських пам’яток» випливають якісь висновки про кулінарні уподобання українців протягом багатьох віків, про причини несприйняття деяких продуктів? Це була вередливість чи дієта? До речі, у таких прізвищах із заперечною часткою не- (Неїжкаша, Неӥжмак, Непийвода, Непийпиво тощо), найвірогідніше, вона вказує саме на несприйняття людиною певних продуктів та напоїв, аніж на заборону дії, тому включення їх до моделі творення прізвищ зі спонукальною формою дієслова + іменник (с. 20) вважаємо сумнівним.

У невеликому розділі про українські прізвища з компонентом -біл- (с. 273-280) автор розглянув за семантикою і способами творення прізвища, що походять від назви місцевості або конкретних населених пунктів (Білаєнко, Білецький, Білич, Білинчук, Білицький, Біловод, Білорус, Білочерківець, Білочерківський, Білосточький, Білопільський); прізвища на позначення професійних занять (Білоткач, Біловар, Біловарій, Біловарчук, Білотчук, Забіла, Забілинський), індивідуальних ознак за зовнішнім виглядом (Білан, Біланчик, Біленко, Біленький, Білець, Білий, Білак, Білаш, Білко, Білевич, Білуха, Білусяк, Біляченко та ін.), на позначення частин людського тіла та їх кольорофункцій (Білак, Білан, Білун, Білуха, Білоголовий, Білоусенко, Білоусько, Білобровка, Білозуб, Білокур, Білокучма, Білоциия, Білоцицьк, а Білобородько, Білоніжка, Білоножко, Білоноженко, Білогуб, Білоокий); прізвища, пов'язані з кольоровими ознаками одягу (Білошапка, Білошапенко, Білорукавський, Білоштан); прізвища, утворені від назв тварин та частин їх тіла, а також рослин за кольоровою ознакою (Білововк, Біловіл, Біловол, Білокінь, Білоконь, Білоконенко, Білокобильський, Білокіз, Білозір, Білодуб) та окрему групу прізвищ з непрозорою семантикою (Біліба, Більговський, Більдер, Більдій, Більдін, Більдюк, Біляба, Біланд, Білограс та ін.), «які є цікавим матеріалом для етимологічних студій, оскільки уможливлюють виявлення архаїчної та рідковживаної лексики» (с. 277).

Увагу вченого привернула низка (понад 20) прізвищ 3 основою біл(о)- людей, які уславилися своїм творчим внеском у нашу науку, культуру та мистецтво (Білий, Білецький, Білодід, Білямівський, Білоградський, Білозір, Білинник, Білецький-Носенко, Білик, Білиловський, Білоус, Білинський, Білостоцький, Білявський, Білокур, Забіла та ін.) (с. 278).

У завершальному нарисі «Українські прізвища 3 компонентом лих-» привертає увагу їх авторська класифікація, яка засвідчує, що первісні носії цих прізвищ були переважно антигуманними людьми: вони чинили лихо, викликали страждання (Лихий, Лихавчук, Лиходій, Лихочький, Лиходієвський, Лихонос, Лихоносенко, Лихоноша, Лиховій, Лихота, Лиховченко, Лихуша, Лихоцький, Лихолай та ін.). Проте такі прізвиська (прізвища) люди діставали й за іншими ознаками: за винятковими здібностями (Лихограй, Лихоігренко «той, хто майстерно грає на музичних інструментах», Лихопій, Лихопой «талановитий співець», Лихошва, Лихошвай «той, хто гарно шиє одяг», Лихопека «вправний пекар»), за місцем проживання (Лихогорський), за національною ознакою (Лихошвед), за ставленням до праці (Лихолеженко «ледар, ледацюга»), за станом здоров'я (Лихогруд «особа великої фізичної сили») тощо (c. 294-295).

Автор наводить список 80-ти відомих на цей час прізвищ із компонентом лих-, у яких «віддзеркалені значною мірою як негативні, так і позитивні риси характеру певних особистостей персонажів прізвиськових назв українського суспільства, які 3 часом успадкувалися їхніми нащадками як офіційні прізвища, зберігаючи первісне значення чи втрачаючи його і набуваючи нових смислових відтінків» (с. 297). Серед носіїв таких прізвищ дослідник віднайшов майже 30 відомих особистостей, які відіграли історичну роль у державотворчому процесі України: військовиків, діячів науки, культури і мистецтва.

А. М. Поповський скромно назвав свою монографію «Дещиця...», тобто «малість, дрібниця» (від займенника дещо «небагато чого; що-небудь, щось»), очевидно, маючи на увазі те, що він розглянув лише українські прізвища 3 прозорою семантикою, утворені за різними моделями і з різними компонентами та коренями. Але ж це найчисельніші й найпоширеніші групи прізвищ, що становлять основу українського ономастикону.

Чимало українських прізвищ залишилося поза увагою автора рецензованої мо- 
нографії, проте вони не викликають особливого дослідницького інтересу.

Не потребують жодних тлумачень прізвища, пов'язані з професією чи видами занять їх носіїв: Бондар, Коваль, Коваленко Кравеиь, Мельник, Мірошник, Мірошниченко, Пастух, Рибалка, Скляр, Скляренко, Слюсар, Слюсаренко, Староста, Стельмах, Шаповал, Шаповаленко і т. ін. Прозорі за семантикою, проте не завжди ясні за мотивацією й часом появи прізвища, утворені від назв рослин (Барвінок, Береза, Березовський, Верба, Калина, Клен, Липа, Осика, Тополя, Явір, Яворівський, Гай, Діброва, Кущ і т. ін., але ж немає таких як Акація, Ліщина Порічка і т. ін.), назв тварин, птахів і риб (Баран, Борсук, Ворона, Горобещь, Жайворонок, Зозуля, Карась, Кіт, Коза, Лис, Лисиия, Окунь, Орел, Півень, Рак, Синиия, Сова, Сокіл, Сорока, Чай$к а$, Чиж, Чорногуз, Щука), явищ природи (Зима, Вихор, Вітер, Грома, але чи є десь Весна, Літо, Осінь, Дощ, Сніг, Туман?). Ці та деякі інші проблеми, пов'язані з українськими прізвищами, ще чекають на своїх дослідників.

Крім «дещиці» про українські прізвища, в рецензованій монографії є ще й дещиця іншого матеріалу, що зайняв майже половину іiі обсягу (140 с. із загальних 290 с.). Автор включив до неї 8 раніше опублікованих у мовознавчій періодиці статей, безпосередньо не пов'язаних з українськими прізвищами, проте в них ідеться про певні реалії українського побуту та деякі риси української ментальності, порушуються важливі моральні та етичні проблеми в житті сучасного українського суспільства тощо.

Уже після першого нарису про українські прізвища зі спонукальними компонентами автор у розлогій статті детально аналізує слово борщ (с. 39-67) в ономастичному та апелятивному контексті «мовної стихії нашого народу та майстрів художнього слова» (с. 39), а далі досліджує етимологію та лексико-семантичні зміни протягом століть у слові хам, аналізує своєрідне значення для українців слова лобода, викладає когнітивні погляди на лексико-семантичне поле «прислужництво», критикує зросійщення українських прізвищ під впливом соціально-політичних, правових і культурних чинників, що діяли протягом тривалого часу на території України, коли частина національних прізвищевих ознак зникла, а їхня структура спотворювалася і натомість укорінювалися інонаціональні риси. Далі автор виявляє функціональний потенціал лексичних та семантичних особливостей слова перекотиполе.

Завершується цей цикл аналізом історії магічного слова перевертень, яке від свого первісного значення «людина, обернута чаклуванням на тварину або який-небудь предмет», з часом набуло додаткового значення «людина, що зрадила свої переконання». Українські прізвиськові назви з народних повір'їв успадкувалися антропонімами Перевертень, Перевертун, Перевертюк та ін.

Перевертні «не зійшли з арени й сьогоднішнього суспільного життя українського народу. Саме на таких, вірнопідданих малоросів, робить ставку тепер Москва, після розпаду Радянського Союзу, щоб повернути в лоно російської імперії суверенну Україну» (с. 284).

Іншотемні статті автор монографії подав упереміш зі статтями про українські прізвища. Така композиція створює неоднозначне враження: з одного боку, додаткові матеріали урізноманітнюють виклад, ненав'язливо, ніби між іншим інформують про лексичне багатство української мови та про вагомі й потрібні для патріотичного виховання громадян факти і явища; з іншого ж боку, цей матеріал випадає із заявленої тематики і не відповідає назві книжки. Можливо, було б доцільніше зробити його додатком або розширити назву монографії й розділити ії на дві частини.

Принципових зауважень щодо тексту монографії ми не маємо. Вона написана на високому науковому рівні вишуканою літературною мовою. Список скорочень i бібліографічні посилання оформлені з дотриманням усіх нині чинних вимог.

Деякі авторські недогляди неістотні й при уважнішому коректуванні могли б бути легко помічені. Зокрема, ім'я видатного діяча української культури XVI-XVII ст. Беринди (1560-1632) було Памвó, а не Па́мва (с.155). Історію слів хор, хорей, хореографія досліджував не Г. А., а Г. П. Півторак (с. 90, 112). У монографії в межах тієї самої статті другий абзац на с. 204 дублюється на с. 212 (останній абзац). Багато помилок у назвах праць М. Гринблата і М. Бірила білоруською мовою (с. 256-157). На відміну від російської, у білоруській мові дві крапки над літерою ё такі ж обов'язкові, як і в українській над літерою ї, якої в білоруській абетці немає. На письмі послідовно позначається акання і твердість білоруських шиплячих приголосних тощо. Відтак мало б бути: Грынблат M. Анамастыка як крыніца вывучэння 
гісторыі і этнаграфіі беларускага народа (на матэрыялах беларускіх прозвішчаў (1958); Бірыла М. Беларуская антрапанімія: уласныя імёны, мянушкі, імёны па бацьку, прозвішчы (1966).

Рецензована монографія А. М. Поповського приваблює також чудовим художнім оформленням і високоякісним друком. 3 наукового погляду вона здається нам найгрунтовнішим і найінформативнішим дослідженням серед наявних праць про українські прізвища і $є$ вагомим внеском у сучасне українське мовознавство.

\section{Г. Півторак}

Інститут мовознавства ім. О. О. Потебні НАН України

м. Київ, Україна

Електронна пошта: muzling@ukr.net

http:// orcid.org/0000-0002-0646-694X

\section{H. Pivtorak}

O. O. Potebnia Institute of Linguistics of the National Academy of Sciences

of Ukraine

Kyiv, Ukraine

E-mail: muzling@ukr.net

http:// orcid.org/0000-0002-0646-694X

Popovskyi A.

SOMETHING ON UKRAINIAN SURNAMES

Dnipro : Lira, 2020. 300 p.

Дата надходження до редакції - 16.09.2020

Дата затвердження редакцією — 17.09.2020

DOI 10.33190/0027-2833-314-2020-5-007

Тищенко К. М.

42 ЕПОХИ УКРАЇНСЬКИХ МОВНИХ КОНТАКТІВ: ЕНЦИКЛОПЕДІЯ 3000 ЗАПОЗИЧЕНИХ РЕАЛІЙ АНТИЧНОСТІ Й СЕРЕДНЬОВІЧЧЯ У МОВІ, ПРІЗВИЩАХ І ТОПОНІМАХ

Київ ; Броди : Просвіта, 2020. 912 с.

Нова книга Костянтина Тищенка, професора кафедри мов і літератур Близького й Середнього Сходу Інституту філології Київського національного університету імені Тараса Шевченка, являє собою енциклопедичний словник, у якому систематизовано й проетимологізовано понад 3000 запозичень в українській лексиці, прізвищах українців і топонімах на теренах України. Це підсумок восьми монографій автора (2006-2018) з різних аспектів теми. Рецензована книга викладає нову концепцію історії українських мовних контактів. Водночас це й сучасний синтез знань про багатовікову історію запозичень в українську мову.

Зв'язки українців з іншими народами лишили в мові безліч слідів і прослідків. Не можна сказати, що вони малодосліджені. Утім, як показує автор, у цій ділянці досі лишається чимало білих плям, надто в історичній топонімії (гідроніми, ойконіми) та антропонімії (прізвища). При етимологізуванні власних назв не рідкість їх безпідставне «ослов' янювання», нехтування східним контекстом минулого України. Наскільки цей контекст багатий, настільки ж занедбані його студії. Одна з причин успадкований від радянських часів брак сходознавчої освіти.

У виданні на конкретному матеріалі втілено ідею В. В. Мартинова (1989), згідно 3 якою кожна мова пережила стільки станів, скільки мала у своїй історії епох контактів із сусідніми мовами. За висновком К. М. Тищенка, українську мову сфор- 